\title{
Archaeological Testing of Site 41KR210 Kerr County, Texas
}

Joe T. Denton

Follow this and additional works at: https://scholarworks.sfasu.edu/ita

Part of the American Material Culture Commons, Archaeological Anthropology Commons, Environmental Studies Commons, Other American Studies Commons, Other Arts and Humanities Commons, Other History of Art, Architecture, and Archaeology Commons, and the United States History Commons

Tell us how this article helped you.

This Article is brought to you for free and open access by the Center for Regional Heritage Research at SFA ScholarWorks. It has been accepted for inclusion in Index of Texas Archaeology: Open Access Gray Literature from the Lone Star State by an authorized editor of SFA ScholarWorks. For more information, please contact cdsscholarworks@sfasu.edu. 


\section{Archaeological Testing of Site 41KR210 Kerr County, Texas}

\section{Licensing Statement}

This is a work produced for the Texas Department of Transportation (TxDOT) by the report producer. TxDOT and the report producer jointly own all rights, title, and interest in and to all intellectual property developed under TXDOT's contract with the report producer. The report may be cited and brief passages from this publication may be reproduced without permission provided that credit is given to both TxDOT and the report producer. Permission to reprint an entire chapter, section, figures or tables must be obtained in advance from either the Supervisor of the Archeological Studies Branch, Environmental Affairs Division, Texas Department of Transportation, 125 East 11th Street, Austin, Texas, 78701 or from the report producer. 


\section{ARCHAEOLOGICAL TESTING OF SITE 41KR210 \\ KERR COUNTY, TEXAS}

B y

Joe T. Denton

Texas

State Department of Highways and Public Transportation

Highway Design Division

June 1983 
ABSTRACT

Testing of archaeological Site 41KR210 was undertaken in January, 1983, in accordance with provisions of the Memorandum of Understanding between the State Department of Highways and Public Transportation (SDHPT) and the Texas Antiquities Committee. Testing was to determine site depth, cultural context, and archaeological significance. Archaeological Site 41KR210 was typified by shallow deposits of cultural material which included lithic material and scattered burned rock.

Results of the test indicate that Site $41 \mathrm{KR} 210$ is of Archaic age and represents a limited manifestation of a lithic manufacturing station and campsite. The limited depth and nature of the site indicate that the site is not eligible for inclusion in the National Register.

\section{INTRODUCTION}

Archaeological Site 41KR210 was reported in March, 1982, by Daymond D. Crawford of the SDHPT and was recommended for testing. Testing was conducted by the author and personnel provided by the local SDHPT office during January, 1983, in accordance with the Procedures for the Protection of Historic and Cultural Properties (36 CFR, Part 800). The objective of the test was to determine eligibility to the National Register, as prescribed by law, and to determine the nature of the deposits and cultural context.

Site $41 K R 210$ is located on proposed Spur 535 on the second terrace of the Guadalupe River where the terrace is truncated by a small wet-weather stream. The terrace is dominated by a limestone bench which forms the high terrace above the floodplain. The hillside at this point is approximately 60 feet above the normal flow of the Guadalupe River (Fig. 1).

The area today is typified as open oak savanna with a shrub understory and short grasses. The soils are gravels and limestone derived from numerous and widespread outcrops of soft and hard limestones. The soil at the site is shallow with only a few areas of deeper deposits.

Surface indications show the site to be extensive and typified by lithic debris and scattered burned rock. No discrete and intact features, i.e., hearths and/or middens, were noted. 


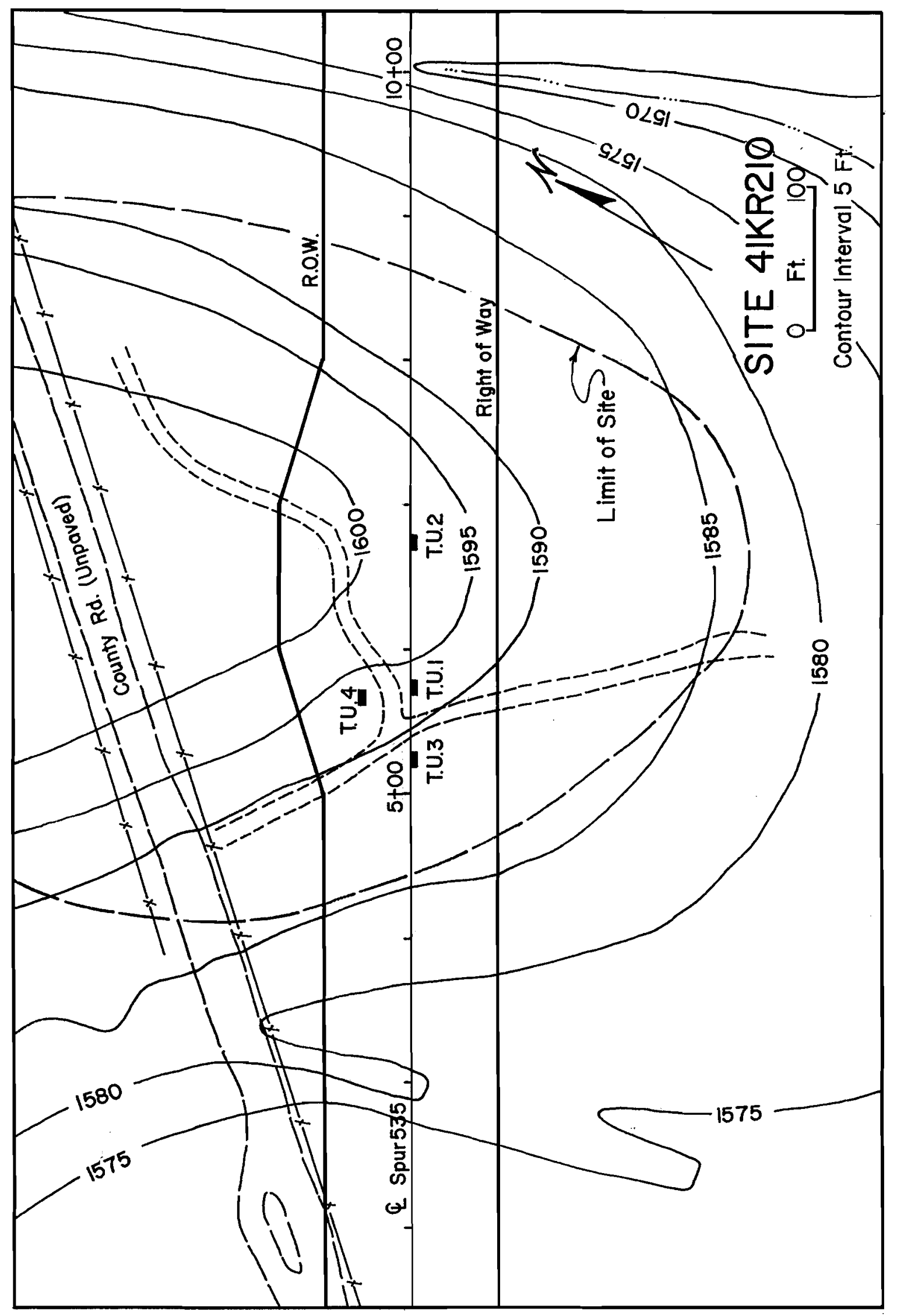

OD 
ARCHAEOLOGICAL BACKGROUND

Kerr County has benefited by numerous archaeological investigations by both professional and avocational archaeologists, thus providing a good basis for the establishment of a cultural sequence for the area.

The Paleo-Indian Period is the least represented period for the area; the Archaic and Late Prehistoric Periods are represented in good archaeological context. Archaeological Site $41 \mathrm{KR} 210$ is a manisfestation of the Archaic Period.

Recent interpretations of the Archaic Period in Central Texas have changed the terminology from the use of cultural periods to the use of cultural phases (Weir 1976). The Archaic cultural sequence has been established as the San Geronimo Phase, 8000-4500 B.P.; the Clear Fork Phase, 50004000 B.P.; the Round Rock Phase, 4200-2600 B.P.; the San Mareos Phase, 2800-1800 B.P.; and the Twin Sisters Phase, 2000-700 B.P. Table 1 presents these phases and the corresponding diagnostic projectile point types.

Table 1. Central Texas Archaic phases and their corresponding diagnostic dart point types.

PHASE

\begin{tabular}{l|l}
\hline Twin Sisters & Ensor, Frio, Fairland, Godley, Darl \\
San Marcos & Castroville, Montell, Marshall, Marcos, \\
& Lange \\
Round Rock & Pedernales \\
Clear Fork & Bulverde, Nolan, Tortugas, Travis \\
San Geronimo & Early Barbed, Be ll, Angostura, Gower, \\
& Uvalde, Martindale \\
\hline
\end{tabular}

The archaeology of Kerr County has been explored since 1934 by numerous individuals and organizations. The majority of the investigations have centered around Archaic sites with some investigation of Late Prehistoric sites. The archaeological sites in Kerr County run the full range of types of sites including burned rock middens, shelters, quarry sites, and terrace sites.

A discussion of the sites investigated in Kerr County has been previously published by Luke (1980) and will not be restated here. 


\section{PROCEDURES}

During the course of investigation of Site $41 \mathrm{KR} 210$ a total of four test units was excavated nonrandomly over the site. These test units were 1 by 2 meter units placed in areas with obvious soil deposits or high evidence of eroding material. Test Unit 2 was situated to investigate a possible hearth or burned rock cluster while Test Units $\mathbf{1}, \mathbf{3}$, and 4 were placed in areas believed to contain some depth (Fig. 1). Only in one test unit, Test Unit 1 , were excavations able to attain any depth (Fig. 1 ) Each unit was excavated by trowel, pick, and shovel in arbitrary $10 \mathrm{~cm} \mathrm{levels} \mathrm{and} \mathrm{was} \mathrm{screened} \mathrm{through} \mathrm{1/4"} \mathrm{hardware} \mathrm{cloth.}$ The recovered debitage and tools were placed in bags labeled as to provenience and were retained for analysis.

\section{ARTIFACTS}

The test resulted in the recovery of 3 bifaces and biface fragments ineluding 2 projectile point fragments, 2 unifaces, and 9 modified flakes. Also recovered were 8 cores and 325 flakes. No bone or mussel shell was found during the test.

\section{BIFACES}

Thinned Bifaces (3 specimens) (Fig. 2A-C)

Only one specimen is complete enough for identification as to type. This specimen (Fig. 2A) has broad, thin blades with straight edges and slight barbs. The stem is short but expanding with basal thinning that produces a concave base. Manufacture of the point appears to be well executed; however, one side does exhibit a number of small hinge flakes along the edge which possibly resulted in the removal of one barb and shoulder. The distal tip appears to have been lost from a shearing impact or snapping during manufacture. Except for the concave base, this projectile point resembles the $M$ arcos type as described by Suhm, Krieger and Jelks (1954). Provenience: Test Unit 1, Level 2.

An additional projectile point fragment was recovered but identification is uncertain. The fragment (Fig. 2B) is a medial section that broke at the stem and tip. In outline the point appears to be similar to the Marcos-like point recovered in Test Unit $\mathbf{1}$. It is, however, somewhat thinner with good overall workmanship. The blade is wide with straight edges. Provenience: Test Unit 3, Level 2. 


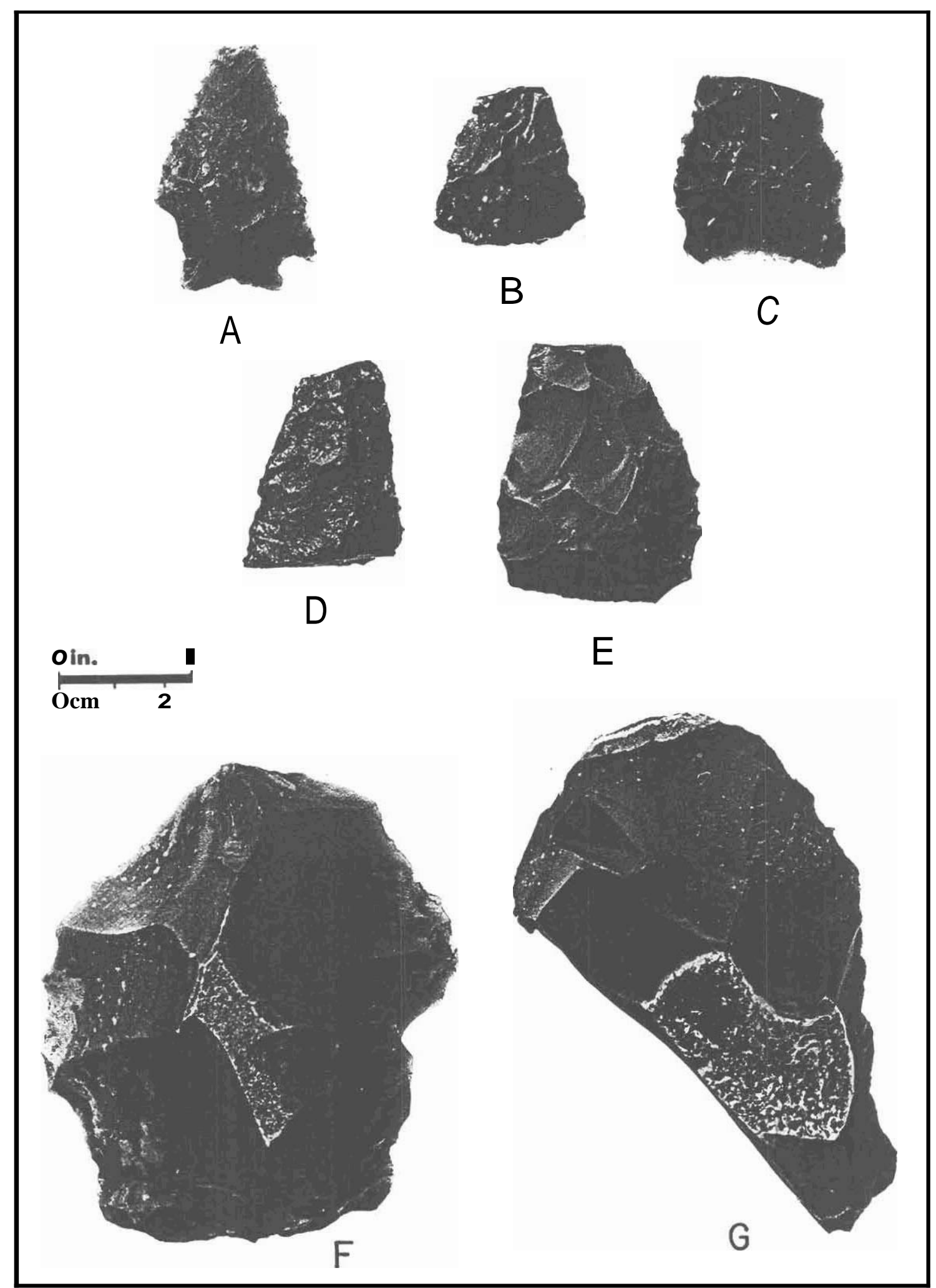

FIGURE 2. Bifaces. A-C, thinned bifaces; $D, E$, miscellaneous bifaces; $F, G$, core bifaces. 
A third thinned biface (Fig. 2C), although triangular in outline, is believed to be a preform. Workmanship is good with billet flake scars over most of the surface. It appears to have been snapped during manufacture and discarded. The base is thin with some edge preparation on the corners. Provenience: Test Unit 1, Level 1.

Miscellaneous Bifaces (2 specimens) (Fig. 2 D, E)

These two bifaces do not exhibit the broad thin flake scars indicative of biface thinning. The specimen illustrated in Figure $2 \mathrm{D}$ was heat fractured which obliterated one face of the blade. The blade appears to have been long and has a thick midsection. Some cortex is evident on the blade surface. The edges are slightly uneven with some crushing. Provenience: Test Unit 1, Level 1.

The specimen illustrated in Figure $2 E$ exhibits strong flake scars over a subtriangular blade. The edge outline is slightly to strongly convex with a straight base. The tip has been lost due to a snap. The blade edge is slightly sinuous, with some evidence of edge preparation. Provenience:

Test Unit 1, Level 1.

Core Bifaces (2 specimens) (Fig. 2F, G)

Two bifaces were recovered that are the result of primary decortification. Both specimens exhibit some cortex on at least one surface of the biface. Manufacture is by hard-hammer percussion with wide and deep flake scars. The edges are sinuous and one specimen (Fig. 2F) exhibits some edge crushing. The specimen illustrated in Figure $2 \mathrm{~F}$ was recovered in Test Unit $\mathbf{1}$, Level 2, and the specimen illustrated in Figure $2 \mathrm{G}$ was located in Test Unit 4, Level 1.

Unifaces (2 specimens) (Fig. 3A, B)

Only two unifaces were recovered. An end scraper (Fig. 3A) was recovered in Test Unit 1, Level 2. The scraper bit was formed on the distal end of a thick flake. The bit area is well rounded and does not display any obvious wear. Some cortex is present on the platform and on the dorsal surface of the scraper.

The other uniface (Fig. 3B), also recovered from Test Unit 1, Level 2, is a large cortex flake with a recurving prepared edge. The edge is thin and formed by the removal of small flakes to form a straight edge. No wear is evident on the edge. 


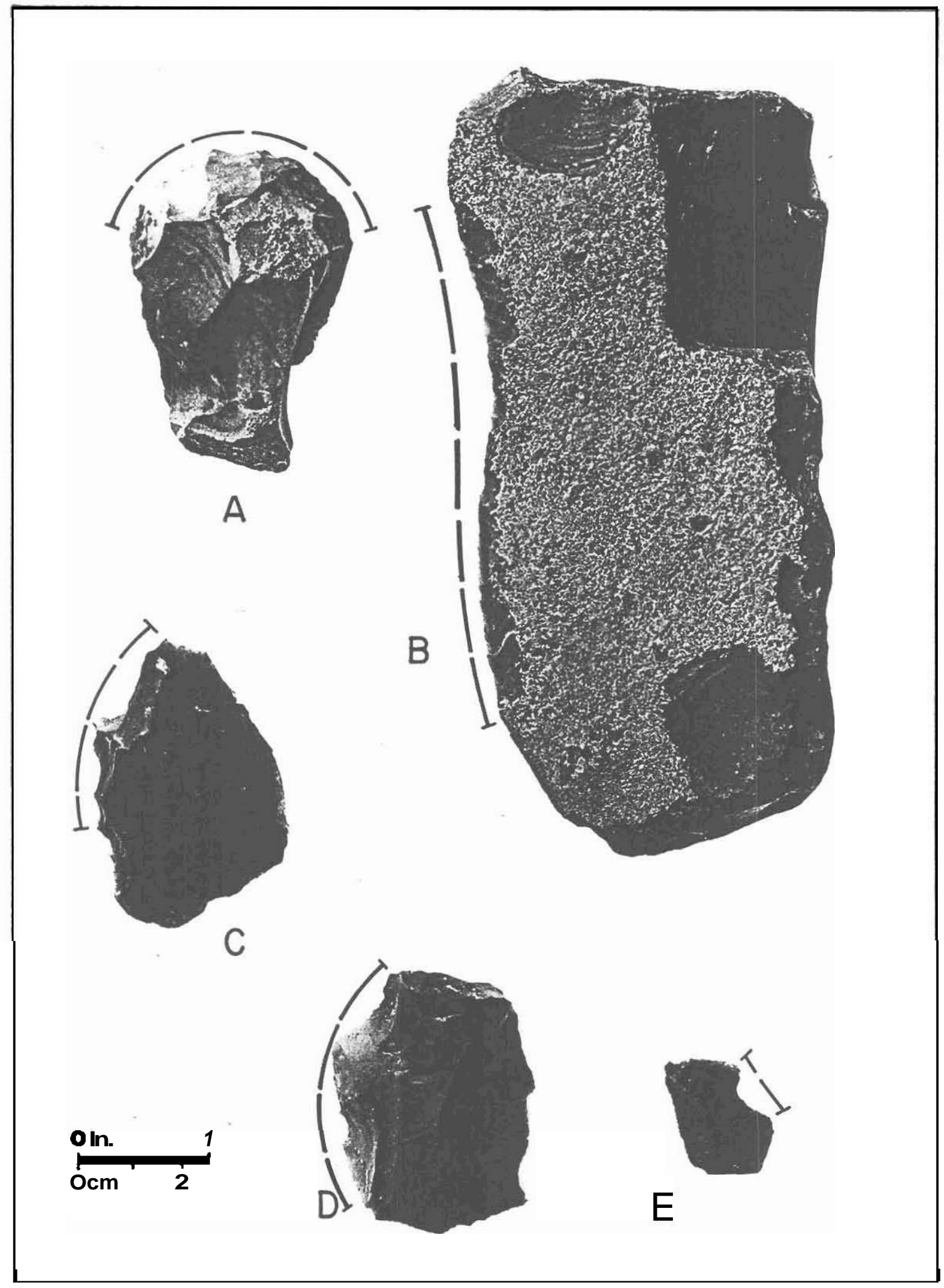

FIGURE 3. Unifaces and modified flakes. Worked edges are indicated. A,B, unifaces; C,D, modified flakes; E, spoke shave. 
Cores (8 specimens)

Eight cores were recovered during the test. All the cores are from ledge flint, and the colors are primarily a light gray or tan. Two cores are of a darker gray flint. Test Unit 1 produced 5 cores and Test Unit 4 produced 3 cores. Only one core occurred in a level other than Level 1, and this was in Level 3.

Modified Flakes (9 specimens) (Fig. 3C-E)

A total of 9 modified flakes was recovered, six of which exhibit small bit-like areas. Two specimens (Fig. 3C,D) show modification lateral to the platform on the flake edge. Both are strong thick flakes. The modification is a beak-like projection similar to a graver beak. The edges produced are strong and steep.

One specimen (Fig. 3E) is a spoke shave produced on a small flake. The spoke shave bit is $9.5 \mathrm{~mm}$ wide and $2.5 \mathrm{~mm}$ deep. No evidence of wear was observed.

A $n$ additional six modified flakes were recovered that exhibit small areas of modification in apparently random areas of the flake.

Unmodified Flakes (325 specimens)

An additional 325 flakes were recovered, the majority of which occurred in Test Unit 1, Level 1. Analysis of flake morphology was not attempted due to the nature of the deposits and relative paucity of materials.

\section{ARTIFACT DISTRIBUTION}

In the area of Site $41 \mathrm{KR} 210$ which is to be impacted by construction, the artifacts appeared to be concentrated in shallow deposits on the southern and eastern slopes of the small hillside. The test unit on top of the hill, Test Unit 2, yielded only 2 flakes and a few recent historic (post1930) artifacts. This area was previously noted to have an accumulation of burned rock. This accumulation was scattered and deflated into a zone of hard and compact gravel.

The central area investigated, Test Units 1 and 4, contained the majority of the artifacts and flakes. The deposits, however, were widely varied. 
Test Unit 1 was in an area of clay loam soil deposits with a depth of 35 to $40 \mathrm{~cm}$ and eroded limestone deposits in the 30 to $40 \mathrm{~cm}$ range. Test Unit 4 was located approximately 50 feet to the northwest of Test Unit 1 and the soil depth was a maximum of $12 \mathrm{to} 15 \mathrm{~cm}$ above the limestone.

Test Unit 1 was most productive with a projectile point preform, a Marcoslike projectile point, and numerous artifacts associated with campsite and chipping station debris. Although burned rock and fire-fractured flint were present, there was no evidence of features. No charcoal was recovered during the test.

Test Unit 3, the test to the southwest and downslope from the main concentrations in Test Units 1 and 4, revealed a shallow deposit of 18 to 20 $\mathrm{cm}$ depth which was clay loam over eroded bedrock. Although one projectile point fragment was found, the overall flake and artifact count was low. Only a few burned rocks were present and no features were noted.

A breakdown of artifacts by level is presented in Table 2 .

Table 2. Artifact Distribution.

\begin{tabular}{|c|c|c|c|c|c|}
\hline Artifact Class, & Level 1 & Level 2 & Leve1 3 & Leve1 4 & Leve1 5 \\
\hline $\begin{array}{l}\text { Projectile } \\
\text { Points }\end{array}$ & 1 & 2 & & & \\
\hline $\begin{array}{l}\text { Miscellaneous } \\
\text { Bifaces }\end{array}$ & 2 & & & & \\
\hline Core Bifaces & 1 & 1 & & & \\
\hline Unifaces & & 2 & & & \\
\hline Cores & 7 & & 1 & & \\
\hline $\begin{array}{l}\text { Modified } \\
\text { Flakes }\end{array}$ & 5 & 4 & & & \\
\hline Flakes & 212 & 55 & 51 & 4 & 3 \\
\hline
\end{tabular}


SUMMARY

Archaeological Site 41KR210, as evidenced by the SDHPT testing appears to be a shallow lithic processing area and associated campsite. While the area of the site is large, it appears that only small areas were utilized intensively. The area tested was utilized during the San Marcos phase, or 2800-1800 B.P. (Weir 1976), based on the projectile points recovered. Campsite activities are evidenced by the presence of the scrapers and modified flakes. Faunal materials, although expected for a campsite, were nonexistent. The presence of cores, core bifaces, and unfinished artifacts indicates that lithic reduction was a primary activity in the areas tested.

CONCLUSION

The SDHPT testing was limited to a portion of a widely scattered site. On the basis of that test it is believed that the area within the SDHPT right-of-way does not meet the criteria for inclusion to the National Register. Areas to the east of the right-of-way are also shallow, and bedrock is evident in several areas. Areas of the site to the west were inaccessible during the time of investigation but also are presumed to be shallow. The site, if investigated as a whole, might be useful in determining horizontal differences in temporal changes and variations in activity areas. However, no further investigations are warranted within the SDHPT jurisdiction. 


\section{REFERENCES CITED}

Luke, Clive J.

1980 Continuing Archaeology on State Highway 16, The Shep Site (41KR109) and The Wounded Eye Site (41KR107). Texas State Department of Highways and Public Transportation Publications in Archaeology Report 16. Austin.

Suhm, Dee Ann, Alex D. Kreiger, and Edward B. Jelks

1954 An Introductory Handbook of Texas Archeology. Bulletin of the Texas Archeological Society 25.

Weir, Frank A.

1976 The Central Texas Archaic. Ph.D. dissertation, Department of Anthropology, Washington State University, Pullman, Washington. 